\title{
High-Density Lipoproteins in Stroke
}

\author{
Olivier Meilhac
}

\section{Contents}

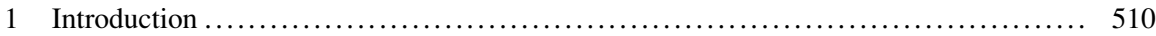

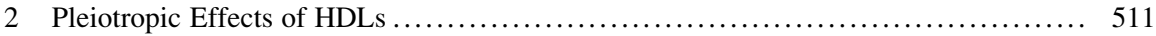

3 HDL Potential Effects on the Blood-Brain Barrier ........................... 511

3.1 Reconstituted HDLs and HDL Mimetics ............................. 512

4 Part 1: Pleiotropic Effects of HDLs - In Vitro and In Vivo Data ................ 512

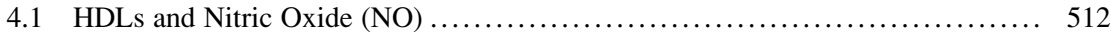

4.2 HDLs and Sphingosine 1-Phosphate .................................. 513

4.3 Antioxidative Stress ................................................ 514

4.4 Anti-inflammatory and Antiprotease Properties ............................ 514

4.5 Endothelial Cell Integrity, EPCs and Antiapoptotic Action .................. 515

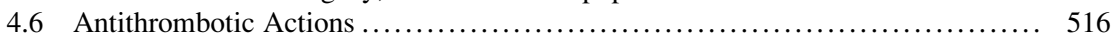

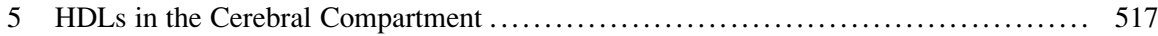

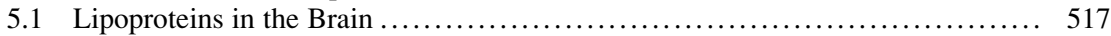

5.2 Plasma HDLs in the Brain ........................................ 518

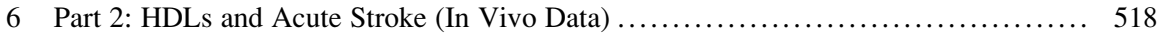

6.1 HDLs and Acute Stroke: Experimental Models .......................... 518

References ............................................................ 520

\section{Abstract}

Besides their well-documented function of reverse transport of cholesterol, highdensity lipoproteins (HDLs) display pleiotropic effects due to their antioxidant, antithrombotic, anti-inflammatory and antiapoptotic properties that may play a

O. Meilhac $(\bowtie)$

Inserm U1148, Paris, France

Université de La Réunion, Saint-Denis, Ile de la Réunion, France

CHU de La Réunion, Saint-Denis, Ile de la Réunion, France

Laboratory for Vascular Translational Research, Inserm U1148,

46 Rue Henri Huchard, 75018 Paris, France

e-mail: olivier.meilhac@inserm.fr

(C) The Author(s) 2015

A. von Eckardstein, D. Kardassis (eds.), High Density Lipoproteins, Handbook of

Experimental Pharmacology 224, DOI 10.1007/978-3-319-09665-0_16 
major protective role in acute stroke, in particular by limiting the deleterious effects of ischaemia on the blood-brain barrier (BBB) and on the parenchymal cerebral compartment. HDLs may also modulate leukocyte and platelet activation, which may also represent an important target that would justify the use of HDL-based therapy in acute stroke. In this review, we will present an update of all the recent findings in HDL biology that could support a potential clinical use of HDL therapy in ischaemic stroke.

\section{Keywords}

HDL • Ischaemic stroke • Endothelium • Animal models

Stroke is usually divided according to the type of cerebrovascular lesion into ischaemic and haemorrhagic stroke. Ischaemia is the leading cause of stroke, due to obstruction within a blood vessel supplying blood to the brain. It accounts for about $80-90 \%$ of all stroke cases. Haemorrhagic stroke occurs when a weakened vessel ruptures due to an aneurysm or arteriovenous malformations. Uncontrolled hypertension is often associated with haemorrhagic stroke.

Numerous epidemiological studies demonstrate that HDLs are a strong independent negative predictor of vascular events (Miller and Miller 1975; Nofer et al. 2002), supporting HDL-raising therapies. The SPARCL study (Stroke Prevention by Aggressive Reduction in Cholesterol Levels) was designed to assess the effects of atorvastatin $80 \mathrm{mg} /$ day in patients who previously experienced a stroke or transient ischaemic attack, but without known coronary heart disease (Amarenco et al. 2003). In this study, a negative correlation between HDL-C levels and stroke recurrence was found among these 4,731 patients, but only when ischaemic stroke was considered. Only baseline HDL-C and LDL/HDL ratio were associated with a good outcome in the ischaemic stroke subgroup (Amarenco et al. 2009). Each $13.7 \mathrm{mg} / \mathrm{dL}(0.35 \mathrm{mmol} / \mathrm{L})$ increment in HDL-C was associated with a $13 \%$ reduction in the risk of ischaemic stroke (Amarenco et al. 2008). Interestingly, decreased LDL levels and high HDL levels did not have any effect on haemorrhagic stroke. In a different study, low HDL-C levels have been also associated with a worse outcome after ischaemic stroke. Of 489 patients treated with rtPA for IS, the low concentration of HDL-C was also associated with a poor prognosis at 3 months (Makihara et al. 2012). More recently, another study in patients with atherosclerotic ischaemic stroke reported that low levels of HDL-C $(\leq 35 \mathrm{mg} / \mathrm{dL})$ at admission were associated with higher stroke severity and poor clinical outcome during follow-up (Yeh et al. 2013).

Data from studies investigating the effect of HDL subfractions on vascular prognosis are conflicting, mainly due to the variety of techniques used to assess HDL particle size (Camont et al. 2011; Krauss 2010). Only the inverse relationship between large HDLs (alpha1) and vascular risk was found in several studies 
(Asztalos et al. 2004; Schaefer and Asztalos 2007; Asztalos and Schaefer 2003). Two large cohorts comprising a total of more than 160,000 people used the Mendelian randomisation single nucleotide polymorphism associated with HDL-C to assess a causative role of HDLs in preventing myocardial infarction (Voight et al. 2012). The authors found no significant relationship and therefore concluded that HDL-C was not causal in vascular disease but merely a risk marker. Another interpretation could be that HDL-C, i.e. cholesterol associated with HDL, is not an appropriate prognostic marker or therapeutic target. Given the pleiotropic functions of HDLs (see below), in particular their protective action on the endothelium (Tran-Dinh et al. 2013), their functionality should be evaluated in addition to the concentration of HDL cholesterol.

The long-term beneficial effect of HDLs has been largely attributed to their role in reverse cholesterol transport and atherosclerotic burden regression. However, short-term HDL elevation has also been shown to be beneficial: in patients with acute coronary syndromes, each $1 \mathrm{mg} / \mathrm{dL}$ increment of HDL-C during the course of a 16-week treatment with atorvastatin resulted in a $1.4 \%$ risk reduction for recurrent adverse events (Olsson et al. 2005).

\section{Pleiotropic Effects of HDLs}

HDLs represent a heterogeneous class of lipoproteins as far as size, shape and composition are concerned. Whereas their principal function is to transport cholesterol from peripheral tissues to the liver, additional functions have been attributed to HDLs, which may depend on their composition in lipids, proteins, vitamins or antioxidant molecules. In this review, we will focus on pleiotropic effects of HDLs other than reverse transport of cholesterol that can impact on stroke at different levels and particularly on ischaemic stroke.

\section{HDL Potential Effects on the Blood-Brain Barrier}

The blood-brain barrier (BBB) is composed of endothelial cells interconnected by means of tight junctions lining the microvasculature of the central nervous system (CNS), pericytes, astrocytes, end feet and neuron processes. The first barrier separating the blood and cerebral compartments is represented by endothelial cells, which play a pivotal role in regulating the traffic of molecules and blood cells. Many protective properties of HDLs have been documented in endothelial cells (Tran-Dinh et al. 2013) and are developed below, including vasodilatation, antioxidant, anti-inflammatory and antiapoptotic effects. However, most of the in vitro results have been obtained using HUVECs (human umbilical vein endothelial cells) or BAEC (bovine aortic endothelial cells), which do not present the same characteristics as endothelial cells composing the $\mathrm{BBB}$, in terms of permeability and establishment of tight junctions. In this review, we will summarise the different effects attributed to HDLs that could support their use as therapeutic tools in acute 
stroke or in secondary prevention. Effects of reconstituted HDLs, HDL mimetics and HDLs isolated from plasma will be presented.

\subsection{Reconstituted HDLs and HDL Mimetics}

Apo A-1 is the major protein of HDLs, able to recruit lipids and organise HDL particles. Reconstituted HDLs consist of an in vitro combination of apo A-I and phospholipids, producing disc-shaped particles resembling nascent HDL. Apo A-I may be either purified from human plasma or produced by recombinant technology. Carriers of the apo A-I Milano mutation, characterised by the replacement of an arginine by a cysteine at position 173, have reduced plasma levels of apo A-I and HDL-C without increased cardiovascular disease (Sirtori et al. 2001). This observation has led to a strong interest in using apo A-I Milano peptides or proteins as potential therapeutic agent to treat cardiovascular disease (Nissen et al. 2003). Intravenous injection of apo A-I Milano in humans was shown to reduce the atheromatous plaque volume in both murine models and in humans.

However, controversial data have been published as to whether apo A-I Milano is more effective than apo A-I in reverse transporting cholesterol. In mice, gene transfer of wild-type human apo A-I and human apo A-I Milano inhibited the progression of native atherosclerosis and allograft vasculopathy to a similar extent. An equivalent increase in endothelial progenitor cell (EPC) number/function and endothelial regeneration in allografts was also observed (Feng et al. 2009). The use of either native or mutated apo A-I may however be beneficial for endothelial protection and repair in pathological situations such as ischaemic stroke.

The lipid-binding activity of apo A-1 was attempted to be mimicked by synthetic peptides containing the class A amphipathic helix modified by phenylalanine residues on the hydrophobic face. Improvement of the apo A-1 mimetic peptide stability was reached by using D-amino acids instead of L-amino acids which are more readily degraded in plasma. For example, D4F was shown to reduce atherosclerotic lesions in apo E-null mice (Navab et al. 2005) and to improve the antiinflammatory properties of HDL in humans (Bloedon et al. 2008). Very few data are currently available on the potential beneficial effects, in stroke, of reconstituted HDLs containing wild-type or mutated apo A-I.

\section{Part 1: Pleiotropic Effects of HDLs-In Vitro and In Vivo Data}

\subsection{HDLs and Nitric Oxide (NO)}

Hypertension represents a major risk factor for stroke, and polymorphisms governing endothelial NO synthase (NOS3) gene expression/function have been reported to increase the risk of stroke (Berger et al. 2007; Howard et al. 2005). A 
recent meta-analysis indicates that NOS3 gene 4b/a, T-786C and G894T polymorphism could be associated with IS (Wang et al. 2013). NO may participate in neuroprotection in cerebral ischaemia by its vasodilatory effects but also by increasing erythrocyte membrane fluidity which could limit the microviscosity (Tsuda et al. 2000). In experimental stroke, administration of NO appears to reduce the infarct volume in both permanent and transient models (Willmot et al. 2005). The results of ongoing clinical studies using NO donors are needed to validate experimental data (Sare et al. 2009). Several lines of evidence suggest that HDLs increase NO bioavailability, in particular via the induction of NOS3 [increased expression and activity (Mineo et al. 2006)]. NO exerts many beneficial effects on the microvasculature during reperfusion including vasodilatation, reflow and decreased permeability (Schulz et al. 2004). The results of the trial "Efficacy of Nitric Oxide in Stroke" are still not available. This study should give more insight into the effects of the glyceryl trinitrate patch (transdermal diffusion of NO) on the outcome post-stroke (ENOS Trial Investigators, 2006).

\subsection{HDLs and Sphingosine 1-Phosphate}

Sphingosine 1-Phosphate (S1P) is an important lipid component identified in HDLs (Kimura et al. 2001) that may account for NO-mediated vasodilatory effects of HDLs (Nofer et al. 2004). S1P is secreted by activated platelets (Yatomi et al. 1995) but mainly transported in plasma by HDL particles (54 \%) (Argraves et al. 2008).

HDLs, and in particular S1P, were demonstrated to directly protect the heart against ischaemia/reperfusion in a mouse model (Theilmeier et al. 2006). The authors report that this protection could be attributed to inhibition of neutrophil recruitment and cardiomyocyte apoptosis in the infarcted area by a mechanism involving $\mathrm{NO}$ and S1P signalling.

S1P has been shown to promote endothelial barrier function in cultured pulmonary endothelial cells (Garcia et al. 2001) by enhancing tight junction formation [in HUVECs (Lee et al. 2006)] and cortical actin assembly (Garcia et al. 2001), resulting in a decreased permeability. HDL-associated S1P was also reported to promote endothelial motility, a process of potential importance in case of vascular injury, via Gi-coupled S1P receptors and the Akt signalling pathway (in HUVECs (Argraves et al. 2008)).

In a model of transient middle cerebral artery occlusion in rats, an agonist or the $\mathrm{S} 1 \mathrm{P}$ receptor 1 was shown to be neuroprotective, after intraperitoneal injection at the time of reperfusion (Hasegawa et al. 2010). Most studies using this agonist (fingolimod or FTY720) report reduced infarct volumes and improved functional outcomes, as summarised in a recent meta-analysis (Liu et al. 2013). This protective effect could be due to a reduced cerebral lymphocyte infiltration (Rolland et al. 2013). In a thromboembolic model, FTY720 was reported to reduce rtPAassociated haemorrhagic transformations (Campos et al. 2013). Since HDL particles are the major transporter of S1P, it could be expected that at least part of their beneficial effect on the BBB could be attributed to this sphingolipid. 


\subsection{Antioxidative Stress}

In stroke, a plethora of studies have shown that oxidative stress is associated with ischaemia and reperfusion and still more so after rtPA treatment. Many experimental studies report that antioxidant treatment displays neuroprotective effects (Margaill et al. 2005). However, hitherto, no concluding clinical study could provide evidence of a potential benefit of antioxidant therapy in stroke (Amaro and Chamorro 2011).

Antiatherogenic functions of HDLs have been related, at least in part, to their antioxidant properties. HDLs contain lipid-soluble vitamins, antioxidants and enzymes such as paraoxonase 1 (PON1), platelet-activating factor acetylhydrolase (PAF-AH) and glutathione phospholipid peroxidase (Florentin et al. 2008). Apo A-I and apo A-II also display antioxidant properties. This antioxidant arsenal confers to HDLs the capacity to limit LDL oxidation and to scavenge lipid hydroperoxides (Navab et al. 2000; Negre-Salvayre et al. 2006). In a rat model of renal ischaemia/ reperfusion, rHDLs were shown to reduce the severity of acute ischaemic renal failure associated with decreased malondialdehyde, suggesting attenuation of lipid peroxidation subsequent to oxidative stress (Thiemermann et al. 2003).

\subsection{Anti-inflammatory and Antiprotease Properties}

Acute stroke is characterised by an activated endothelium favouring the recruitment of leukocytes. In particular, neutrophil proteases such as elastase and matrix metalloprotease-9 may induce BBB breakdown and produce deleterious effects on the parenchymal compartment (Stowe et al. 2009). Proinflammatory cytokines such as tumour necrosis factor-alpha (TNF-alpha), interleukin-1 (IL-1) and IL-6 are increased in plasma of patients with acute stroke (Tuttolomondo et al. 2008).

HDLs may exert anti-inflammatory effects on the endothelium but also on leukocytes. In endothelial cells, HDLs (both native and rHDLs) inhibited TNF $\alpha$ and IL-1 induction of leukocyte adhesion molecules VCAM-1, ICAM-1 and E-selectin but had no effect on the expression of platelet endothelial cell adhesion molecule (PECAM) (Cockerill et al. 1995). More recently, McGrath and colleagues reported that the modulatory effects of rHDL on endothelial cells stimulated TNF-alpha and were mediated by DHCR24, an antioxidant enzyme involved in cholesterol biosynthesis (McGrath et al. 2009). Reconstituted HDLs were also reported to limit PMN adhesion to endothelial cells stimulated by TNF $\alpha$ and LPS (Moudry et al. 1997). These effects were later confirmed in vitro using both native and rHDL on HUVECs but also in vivo, in a rat model of haemorrhagic shock (Cockerill et al. 2001). In monocytes, HDL reduced activation of CD11b induced by PMA leading to decreased adhesion to an endothelial cell monolayer, monocytic spreading under shear flow, and transmigration. This process was mimicked by apo A-1 and reported to be ABCA1-dependent (Murphy et al. 2008). More recently, the same group reported that plasma HDLs were potent inhibitors of neutrophil activation both in vitro and in vivo, using mice models of inflammation (Murphy 
et al. 2011). In patients with peripheral vascular disease treated by rHDL, they showed a decreased expression of CD11b by neutrophils 5-7 days post-injection versus saline-injected patients. HDLs can also neutralise circulating inflammatory molecules such as C-reactive protein (Wadham et al. 2004) and LPS (Wurfel et al. 1994).

In addition, proteomic studies have shown that HDLs may transport different antiproteases (Karlsson et al. 2005; Vaisar et al. 2007) and in particular alpha-1 antitrypsin (AAT), the natural inhibitor of elastase (Ortiz-Munoz et al. 2009). HDLs displayed antielastase activity and protected vascular cells against elastase-induced apoptosis. Using an in vitro model of BBB (Weksler et al. 2005), we have recently reported that HDLs could limit the deleterious, elastase-mediated role of activated neutrophils under oxygen-glucose deprivation conditions leading to BBB disruption (Bao Dang et al. 2013). In stroke, inhibition of neutrophil elastase may be a therapeutic target, as shown by using specific inhibitors (Ikegame et al. 2010).

\subsection{Endothelial Cell Integrity, EPCs and Antiapoptotic Action}

Apoptosis is an important mechanism involved in BBB breakdown and associated cerebral damage. In vivo imaging of apoptotic cells using annexin $\mathrm{V}$ was reported to be correlated with BBB permeability in patients with acute stroke (Lorberboym et al. 2006). Prevention of apoptosis of all cells composing the neurovascular unit is therefore of major importance to reduce deleterious effects of ischaemia. Plasma HDL-C and apo A-I were reported to prevent apoptosis of endothelial cells induced by mildly oxidised LDL independently of paraoxonase activity (Suc et al. 1997). In this in vitro model (bovine and human endothelial cell lines), HDL binding was specific (receptor-mediated) and HDLs blocked the intracellular calcium increase preceding apoptosis (Escargueil-Blanc et al. 1997). It was suggested that the Apo A-I moiety mediates this cytoprotective effect rather than SP1 (de Souza et al. 2010).

Hypoxia has been reported to induce an autophagic process in endothelial cells (Zhang et al. 2011). Autophagy can be regarded as an adaptive response of the cell to deleterious environmental conditions that could delay apoptosis but could also represent an early step of the apoptotic process. HDLs were shown to inhibit endoplasmic reticulum stress and autophagic response induced by oxidised LDLs in endothelial cells (Muller et al. 2011), suggesting that they impact on very early events of the apoptotic cascade. In the brain, autophagy was significantly increased in the cortex immediately following experimental subarachnoid haemorrhage (SAH) (Lee et al. 2009). During SAH, the BBB is disrupted subsequent to endothelial cell death by apoptosis. In this model, inhibition of apoptosis was shown to significantly reduce the formation of cerebral oedema and associated mortality (Yan et al. 2011). HDLs could thus modulate apoptosis of BBB endothelial cells by preventing autophagy.

Endothelial cell progenitor (EPC) therapy has been envisaged as a potential therapy in stroke [for review, see (Rouhl et al. 2008)]. EPCs can repair damaged vessels and form new ones that could promote recovery after ischaemic injury. In a 
mouse model of transient middle cerebral artery occlusion (tMCAO), systemic delivery of EPCs limited brain damage associated with ischaemic injury (i.e. improved neurovascular repair and long-term neurobehavioral outcomes) (Fan et al. 2010). In rats, EPCs injected $24 \mathrm{~h}$ after tMCAO were shown to reach the injured area and improved functional recovery, potentially attributable to antiapoptotic factors secreted by EPCs (Moubarik et al. 2011). In humans, erythropoietin therapy significantly increased the number of circulating EPCs and improved a 90-day major adverse neurological effect (Yip et al. 2011). Different studies report that reconstituted HDLs may increase circulating EPC number (Tso et al. 2006) and their differentiation from mononuclear cells as well as their angiogenic capacity (Sumi et al. 2007). This was shown in mouse models of endothelial injury in response to LPS and hind limb ischaemia but also in humans after injection of rHDLs in type 2 diabetic patients (van Oostrom et al. 2007). This increase in circulating EPCs was significant at day 7 post-injection. In hypercholesterolemic subjects, HDL concentration was linked to EPC number and function (Rossi et al. 2010). Low EPC number was also reported to be an independent risk factor for endothelial dysfunction in these patients. Petoumenos et al. reported a correlation between circulating EPCs and HDL concentrations in patients with coronary artery disease (Petoumenos et al. 2009). In addition, they have shown that recombinant HDLs improved the function of circulating EPCs in a model of endothelial denudation, which could be one explanation for the vasculoprotective actions of HDLs.

\subsection{Antithrombotic Actions}

In stroke, haemostasis disorders are associated with dysfunction of vascular endothelium, or with abnormalities of or interference with anticoagulant proteins (i.e. protein C, protein S and antithrombin III) (Coull and Clark 1993). However, all factors favouring clot formation may increase the risk of ischaemic stroke, involving all cellular components (endothelium, erythrocytes, platelets and leukocytes).

HDLs may modulate haemostasis by impacting on platelet, red blood cell (RBC) and endothelial functions (Mineo et al. 2006). For example, thrombin-induced endothelial tissue factor expression in vitro was shown to be downregulated by rHDLs (Viswambharan et al. 2004). Since tissue factor induction on endothelial cells is regulated by NO production, HDLs may inhibit its production in response to endotoxins or cytokines, by increasing the synthesis of NO (Yang and Loscalzo 2000).

Apo A-I, its amphipathic peptide analogues and HDLs were also shown to protect erythrocytes against the generation of procoagulant activity (Epand et al. 1994). $\mathrm{HDL}_{2}$ subfraction was reported to be inversely correlated with erythrocyte aggregation in hypercholesterolemic patients (Razavian et al. 1994). A multiple regression analysis demonstrated that this association was independent of fibrinogen, the major determinant of erythrocyte aggregation. The mechanisms 
by which $\mathrm{HDL}_{2}$ may prevent $\mathrm{RBC}$ aggregability have not been elucidated, but this effect is relevant in small-sized arteries where increased blood viscosity may trigger clot formation. Apo A-I, its amphipathic peptide analogues and HDLs were also shown to protect erythrocytes against the generation of procoagulant activity (Epand et al. 1994). HDLs may inhibit phospholipid flip-flop and the associated procoagulant activity. In healthy volunteers receiving low doses of LPS, injection of rHDLs reduced collagen-induced platelet aggregation and modified the procoagulant state associated with endotoxemia (Pajkrt et al. 1997). More recently, reconstituted HDL infusion in patients with type 2 diabetes induced a 50-75\% attenuation of platelet aggregation in response to ADP and collagen (Calkin et al. 2009). In vitro, this effect was shown to be dose-dependent and remained after removal of rHDLs. Ex vivo, under blood flow conditions, rHDL limited thrombus formation on a matrix of collagen. This effect was attributed to the phospholipid moiety of rHDLs, since it was not reproduced by apo A-I, whereas phosphatidylcholine reached the same level of reduction of aggregation as intact rHDLs. However, in this study, plasma HDLs did not display similar in vitro effects on platelet aggregation. The authors suggest that this may be due to limited efflux of cholesterol from platelet membranes induced by native HDLs.

\section{HDLs in the Cerebral Compartment}

\subsection{Lipoproteins in the Brain}

Various studies have described the capacity of the brain to synthesise lipoproteins that are different from plasma lipoproteins (for review, see Wang and Eckel 2014). Lipoproteins found in the cerebrospinal fluid (CSF) mainly originate from astrocytes and are characterised by a small size (resembling the size and density of HDLs) and contain mainly apo E (Ladu et al. 2000; Koch et al. 2001). Apo E, J, $\mathrm{D}$ and A-I are the main apolipoproteins synthesised in the brain, in an age-dependent manner for apo $\mathrm{J}$ and $\mathrm{E}$ (Elliott et al. 2010). Apo $\mathrm{E}$ and more particularly apo $\mathrm{J}$ are thought to be involved in the clearance of amyloid $\beta$-peptide by astrocytes and microglial cells (Mulder et al. 2014; Calero et al. 2000). Most of lipoproteins isolated from the CSF are associated with amyloid $\beta$-peptide and may participate in its polymerisation, transport and clearance (Ladu et al. 2000). The BBB requires a local homeostasis of cholesterol. Whereas astrocytes are thought to be the major lipoprotein factory, neurons may also participate in the regulation of their synthesis and redistribution in the brain (Pfrieger and Ungerer 2011). After cortical spreading depression (a stimulus that provides long-lasting ischaemic tolerance), apo $\mathbf{J}$ expression is increased, suggesting that this apolipoprotein may participate in neuroprotection subsequently to an ischaemic episode (Wiggins et al. 2003). In a model of middle cerebral artery occlusion, apo J-deficient mice displayed a worse structural restoration in the vicinity of the infarct scar as compared to WT mice (Imhof et al. 2006). 


\subsection{Plasma HDLs in the Brain}

Under physiological conditions, it is not clear whether HDLs reach the cerebral parenchymal compartment. Based on in vitro results using bovine cerebral endothelial cells, HDLs have been suggested to cross the BBB via paracellular transport (de Vries et al. 1995). More recent data describe an active process of transcytosis involving receptors for HDLs at the surface of endothelial cells. In particular, SRB1seems to be involved in HDL uptake whereas ABCA1 (ATP-binding cassette transporter A1) is responsible for internalisation of apo A-1 alone (for review, see von Eckardstein and Rohrer 2009). However, most studies on transendothelial transport of HDLs were performed on aortic endothelial cells that may differ from endothelial cells of the BBB. Few studies are available on HDL actions on neurons and astrocytes. Ferretti et al. reported that HDLs reduced oxidative stress and cell death induced by copper ions in rat astrocytes (Ferretti et al. 2003). In rat type I astrocytes and glioma cells, HDLs stimulated DNA synthesis and expression of fibroblast growth factor-2, a potent neurotrophic factor, which was associated with the activation of proliferative intracellular signalling (Malchinkhuu et al. 2003). It is likely that in pathological conditions (haemorrhage or transient increase of BBB permeability), HDLs have an improved access to the cerebral parenchymal compartment and then act on both neurons and astrocytes (Lapergue et al. 2010, 2013).

\section{$6 \quad$ Part 2: HDLs and Acute Stroke (In Vivo Data)}

Under acute stroke conditions, the lipid profile has been reported to be modified (Santos-Silva et al. 2002). These authors have shown that patients with diagnosed ischaemic stroke (CT imaging, $n=21$ ) had lower plasma concentrations of both HDL and apo A-I than healthy subjects with no history of cardiovascular events and normal haematologic values $(n=29)$. Blood was sampled after a 12 -h fasting period. In these patients, leukocyte count was increased relative to controls, but the concentration of granulocytes accounted for most of this increase (monocytes were moderately augmented whereas lymphocyte count was decreased in stroke patients). More importantly, markers of neutrophil activation, including lactoferrin and elastase, were strongly increased in plasma of stroke patients when compared to controls.

\subsection{HDLs and Acute Stroke: Experimental Models}

Few studies have attempted to use HDL therapy in acute stroke. Based on the observation that low HDL cholesterol levels were associated with cerebrovascular events (Sacco et al. 2001; Wannamethee et al. 2000), Paterno et al. showed that pretreatment with reconstituted HDL reduced neuronal damage in two experimental models of stroke in rats (Paterno et al. 2004). They showed that high doses of 
rHDLs $(120 \mathrm{mg} / \mathrm{kg})$ infused $2 \mathrm{~h}$ before the onset of stroke reduced the brain necrotic area by 61 and $76 \%$, respectively, in an excitotoxic (NMDA) and a transient MCAO model of stroke in rats. More recently, we have shown that plasma HDLs $(10 \mathrm{mg} / \mathrm{kg})$, injected immediately or at 3 or $5 \mathrm{~h}$ after stroke, also reduced cerebral infarct volume by 74, 68 and $70 \%$, respectively, in a rat model of thromboembolic stroke (Lapergue et al. 2010). This was associated with a reduced BBB breakdown and decreased neutrophil recruitment in the infarct area. In this model, injection of fluorescent-labelled HDLs showed a staining of endothelial cells (but also glial cells), suggesting that their primary protective effect was on the BBB. Thus, HDLs may be a powerful neuroprotective tool for the treatment of cerebrovascular diseases by preventing BBB breakdown. We have confirmed these in vivo results by a study using a model of BBB in vitro (Bao Dang et al. 2013).

In humans, recombinant tissue plasminogen activator (rtPA) is the only effective fibrinolytic treatment in ischaemic stroke. The disruption of the BBB is involved in oedema and haemorrhagic transformation following tPA treatment. We assessed whether HDL-rtPA combined treatment could improve the safety and efficacy of tPA in experimental stroke. We showed that HDL injection decreased tPA-induced haemorrhagic transformation in two models of focal middle cerebral artery occlusion (MCAO) (embolic and 4-h monofilament MCAO). Both the blood-brain barrier in vitro model and in vivo results support the vasculoprotective action of HDLs on BBB under ischaemic conditions. Finally, HDLs do not interfere with the fibrinolytic activity of rtPA (Lapergue et al. 2013).

\section{Conclusion}

In addition to reverse transport of cholesterol, HDL particles display different protective effects that could support their use in the acute phase of stroke. Different neuroprotective drugs proven to be effective in animal models have failed to translate into clinical settings (Xu and Pan 2013). Early treatments that could be used without interfering with fibrinolytic treatments should be considered as a good option to limit the deleterious effects of ischaemic stroke. HDLs may represent a good candidate, particularly with respect to their protective effects on the endothelium in ischaemia/reperfusion conditions. As discussed by Navab et al., HDL mimetic peptides should be more appropriate for use in chronic settings since they can be administrated orally or by subcutaneous route, whereas reconstituted HDLs may be more suitable for acute treatment by intravenous injection (Navab et al. 2010). Whether apo A-I combined with phospholipids are sufficient to prevent the effects of ischaemia is questionable. It is likely that enrichment of reconstituted HDLs with protective molecules such as antioxidants or antiproteases should provide an optimal beneficial effect as observed when using plasma HDLs isolated from healthy subjects in different animal models of stroke.

Acknowledgements OM's group at Inserm is supported by the Fondation de France, the Fondation Coeur et Artères and the Agence Nationale de la Recherche (ANR JCJC 2010). 
Open Access This chapter is distributed under the terms of the Creative Commons Attribution Noncommercial License, which permits any noncommercial use, distribution, and reproduction in any medium, provided the original author(s) and source are credited.

\section{References}

Amarenco P, Bogousslavsky J, Callahan AS, Goldstein L, Hennerici M, Sillsen H, Welch MA, Zivin J (2003) Design and baseline characteristics of the stroke prevention by aggressive reduction in cholesterol levels (SPARCL) study. Cerebrovasc Dis 16(4):389-395

Amarenco P, Labreuche J, Touboul PJ (2008) High-density lipoprotein-cholesterol and risk of stroke and carotid atherosclerosis: a systematic review. Atherosclerosis 196(2):489-496. doi:10.1016/j.atherosclerosis.2007.07.033

Amarenco P, Goldstein LB, Messig M, O'Neill BJ, Callahan A 3rd, Sillesen H, Hennerici MG, Zivin JA, Welch KM, Investigators S (2009) Relative and cumulative effects of lipid and blood pressure control in the stroke prevention by aggressive reduction in cholesterol levels trial. Stroke 40(7):2486-2492. doi:10.1161/STROKEAHA.108.546135

Amaro S, Chamorro A (2011) Translational stroke research of the combination of thrombolysis and antioxidant therapy. Stroke 42(5):1495-1499. doi:10.1161/STROKEAHA.111.615039

Argraves KM, Gazzolo PJ, Groh EM, Wilkerson BA, Matsuura BS, Twal WO, Hammad SM, Argraves WS (2008) High density lipoprotein-associated sphingosine 1-phosphate promotes endothelial barrier function. J Biol Chem 283(36):25074-25081

Asztalos BF, Schaefer EJ (2003) High-density lipoprotein subpopulations in pathologic conditions. Am J Cardiol 91(7A):12E-17E

Asztalos BF, Cupples LA, Demissie S, Horvath KV, Cox CE, Batista MC, Schaefer EJ (2004) High-density lipoprotein subpopulation profile and coronary heart disease prevalence in male participants of the Framingham Offspring Study. Arterioscler Thromb Vasc Biol 24 (11):2181-2187. doi:10.1161/01.ATV.0000146325.93749.a8

Bao Dang Q, Lapergue B, Tran-Dinh A, Diallo D, Moreno JA, Mazighi M, Romero IA, Weksler B, Michel JB, Amarenco P, Meilhac O (2013) High-density lipoproteins limit neutrophil-induced damage to the blood-brain barrier in vitro. J Cereb Blood Flow Metab 33(4):575-582. doi:10. 1038/jcbfm.2012.206

Berger K, Stogbauer F, Stoll M, Wellmann J, Huge A, Cheng S, Kessler C, John U, Assmann G, Ringelstein EB, Funke H (2007) The glu298asp polymorphism in the nitric oxide synthase 3 gene is associated with the risk of ischemic stroke in two large independent case-control studies. Hum Genet 121(2):169-178. doi:10.1007/s00439-006-0302-2

Bloedon LT, Dunbar R, Duffy D, Pinell-Salles P, Norris R, DeGroot BJ, Movva R, Navab M, Fogelman AM, Rader DJ (2008) Safety, pharmacokinetics, and pharmacodynamics of oral apoA-I mimetic peptide D-4F in high-risk cardiovascular patients. J Lipid Res 49 (6):1344-1352

Calero M, Rostagno A, Matsubara E, Zlokovic B, Frangione B, Ghiso J (2000) Apolipoprotein J (clusterin) and Alzheimer's disease. Microsc Res Tech 50(4):305-315. doi:10.1002/1097-0029 (20000815)50:4<305::AID-JEMT10>3.0.CO;2-L

Calkin AC, Drew BG, Ono A, Duffy SJ, Gordon MV, Schoenwaelder SM, Sviridov D, Cooper ME, Kingwell BA, Jackson SP (2009) Reconstituted high-density lipoprotein attenuates platelet function in individuals with type 2 diabetes mellitus by promoting cholesterol efflux. Circulation 120(21):2095-2104. doi:10.1161/CIRCULATIONAHA.109.870709

Camont L, Chapman MJ, Kontush A (2011) Biological activities of HDL subpopulations and their relevance to cardiovascular disease. Trends Mol Med 17(10):594-603. doi:10.1016/j.molmed. 2011.05.013

Campos F, Qin T, Castillo J, Seo JH, Arai K, Lo EH, Waeber C (2013) Fingolimod reduces hemorrhagic transformation associated with delayed tissue plasminogen activator treatment in 
a mouse thromboembolic model. Stroke 44(2):505-511. doi:10.1161/STROKEAHA.112. 679043

Cockerill GW, Rye KA, Gamble JR, Vadas MA, Barter PJ (1995) High-density lipoproteins inhibit cytokine-induced expression of endothelial cell adhesion molecules. Arterioscler Thromb Vasc Biol 15(11):1987-1994

Cockerill GW, McDonald MC, Mota-Filipe H, Cuzzocrea S, Miller NE, Thiemermann C (2001) High density lipoproteins reduce organ injury and organ dysfunction in a rat model of hemorrhagic shock. Faseb J 15(11):1941-1952

Coull BM, Clark WM (1993) Abnormalities of hemostasis in ischemic stroke. Med Clin North Am 77(1):77-94

de Souza JA, Vindis C, Negre-Salvayre A, Rye KA, Couturier M, Therond P, Chantepie S, Salvayre R, Chapman MJ, Kontush A (2010) Small, dense HDL 3 particles attenuate apoptosis in endothelial cells: pivotal role of apolipoprotein A-I. J Cell Mol Med 14(3):608-620. doi:10. 1111/j.1582-4934.2009.00713.x/JCMM713

de Vries HE, Breedveld B, Kuiper J, de Boer AG, Van Berkel TJ, Breimer DD (1995) Highdensity lipoprotein and cerebral endothelial cells in vitro: interactions and transport. Biochem Pharmacol 50(2):271-273. doi:10.1016/0006-2952(95)00127-L

Elliott DA, Weickert CS, Garner B (2010) Apolipoproteins in the brain: implications for neurological and psychiatric disorders. Clin Lipidol 51(4):555-573. doi:10.2217/CLP.10.37

ENOS Trial Investigators ET (2006) Glyceryl trinitrate vs. control, and continuing vs. stopping temporarily prior antihypertensive therapy, in acute stroke: rationale and design of the efficacy of nitric oxide in stroke (ENOS) trial (ISRCTN99414122). Int J Stroke 1(4):245-249. doi:10. 1111/j.1747-4949.2006.00059.x

Epand RM, Stafford A, Leon B, Lock PE, Tytler EM, Segrest JP, Anantharamaiah GM (1994) HDL and apolipoprotein A-I protect erythrocytes against the generation of procoagulant activity. Arterioscler Thromb 14(11):1775-1783

Escargueil-Blanc I, Meilhac O, Pieraggi MT, Arnal JF, Salvayre R, Negre-Salvayre A (1997) Oxidized LDLs induce massive apoptosis of cultured human endothelial cells through a calcium-dependent pathway. Prevention by aurintricarboxylic acid. Arterioscler Thromb Vasc Biol 17(2):331-339

Fan Y, Shen F, Frenzel T, Zhu W, Ye J, Liu J, Chen Y, Su H, Young WL, Yang GY (2010) Endothelial progenitor cell transplantation improves long-term stroke outcome in mice. Ann Neurol 67(4):488-497. doi:10.1002/ana.21919

Feng Y, Van Craeyveld E, Jacobs F, Lievens J, Snoeys J, De Geest B (2009) Wild-type apo A-I and apo A-I(Milano) gene transfer reduce native and transplant arteriosclerosis to a similar extent. J Mol Med 87(3):287-297

Ferretti G, Bacchetti T, Moroni C, Vignini A, Curatola G (2003) Protective effect of human HDL against $\mathrm{Cu}(2+)$-induced oxidation of astrocytes. J Trace Elem Med Biol 17(Suppl 1):25-30

Florentin M, Liberopoulos EN, Wierzbicki AS, Mikhailidis DP (2008) Multiple actions of highdensity lipoprotein. Curr Opin Cardiol 23(4):370-378. doi:10.1097/HCO.0b013e3283043806/ 00001573-200807000-0001

Garcia JG, Liu F, Verin AD, Birukova A, Dechert MA, Gerthoffer WT, Bamberg JR, English D (2001) Sphingosine 1-phosphate promotes endothelial cell barrier integrity by Edg-dependent cytoskeletal rearrangement. J Clin Invest 108(5):689-701

Hasegawa Y, Suzuki H, Sozen T, Rolland W, Zhang JH (2010) Activation of sphingosine 1-phosphate receptor-1 by FTY720 is neuroprotective after ischemic stroke in rats. Stroke 41 (2):368-374. doi:10.1161/STROKEAHA.109.568899

Howard TD, Giles WH, Xu J, Wozniak MA, Malarcher AM, Lange LA, Macko RF, Basehore MJ, Meyers DA, Cole JW, Kittner SJ (2005) Promoter polymorphisms in the nitric oxide synthase 3 gene are associated with ischemic stroke susceptibility in young black women. Stroke 36 (9):1848-1851. doi:10.1161/01.STR.0000177978.97428.53

Ikegame Y, Yamashita K, Hayashi S, Yoshimura S, Nakashima S, Iwama T (2010) Neutrophil elastase inhibitor prevents ischemic brain damage via reduction of vasogenic edema. Hypertens Res 33(7):703-707. doi:10.1038/hr.2010.58 
Imhof A, Charnay Y, Vallet PG, Aronow B, Kovari E, French LE, Bouras C, Giannakopoulos P (2006) Sustained astrocytic clusterin expression improves remodeling after brain ischemia. Neurobiol Dis 22(2):274-283. doi:10.1016/j.nbd.2005.11.009

Karlsson H, Leanderson P, Tagesson C, Lindahl M (2005) Lipoproteomics II: mapping of proteins in high-density lipoprotein using two-dimensional gel electrophoresis and mass spectrometry. Proteomics 5(5):1431-1445. doi:10.1002/pmic.200401010

Kimura T, Sato K, Kuwabara A, Tomura H, Ishiwara M, Kobayashi I, Ui M, Okajima F (2001) Sphingosine 1-phosphate may be a major component of plasma lipoproteins responsible for the cytoprotective actions in human umbilical vein endothelial cells. J Biol Chem 276 (34):31780-31785. doi:10.1074/jbc.M104353200

Koch S, Donarski N, Goetze K, Kreckel M, Stuerenburg HJ, Buhmann C, Beisiegel U (2001) Characterization of four lipoprotein classes in human cerebrospinal fluid. J Lipid Res 42 (7):1143-1151

Krauss RM (2010) Lipoprotein subfractions and cardiovascular disease risk. Curr Opin Lipidol 21 (4):305-311. doi:10.1097/MOL.0b013e32833b7756

Ladu MJ, Reardon C, Van Eldik L, Fagan AM, Bu G, Holtzman D, Getz GS (2000) Lipoproteins in the central nervous system. Ann N Y Acad Sci 903:167-175

Lapergue B, Moreno JA, Dang BQ, Coutard M, Delbosc S, Raphaeli G, Auge N, Klein I, Mazighi M, Michel JB, Amarenco P, Meilhac O (2010) Protective effect of high-density lipoprotein-based therapy in a model of embolic stroke. Stroke 41(7):1536-1542. doi:10. 1161/STROKEAHA.110.581512

Lapergue B, Dang BQ, Desilles JP, Ortiz-Munoz G, Delbosc S, Loyau S, Louedec L, Couraud PO, Mazighi M, Michel JB, Meilhac O, Amarenco P (2013) High-density lipoprotein-based therapy reduces the hemorrhagic complications associated with tissue plasminogen activator treatment in experimental stroke. Stroke 44(3):699-707. doi:10.1161/STROKEAHA.112.667832

Lee JF, Zeng Q, Ozaki H, Wang L, Hand AR, Hla T, Wang E, Lee MJ (2006) Dual roles of tight junction-associated protein, zonula occludens-1, in sphingosine 1-phosphate-mediated endothelial chemotaxis and barrier integrity. J Biol Chem 281(39):29190-29200

Lee JY, He Y, Sagher O, Keep R, Hua Y, Xi G (2009) Activated autophagy pathway in experimental subarachnoid hemorrhage. Brain Res 1287:126-135. doi:10.1016/j.brainres. 2009.06.028/S0006-8993(09)01185-8

Liu J, Zhang C, Tao W, Liu M (2013) Systematic review and meta-analysis of the efficacy of sphingosine-1-phosphate (S1P) receptor agonist FTY720 (fingolimod) in animal models of stroke. Int J Neurosci 123(3):163-169. doi:10.3109/00207454.2012.749255

Lorberboym M, Blankenberg FG, Sadeh M, Lampl Y (2006) In vivo imaging of apoptosis in patients with acute stroke: correlation with blood-brain barrier permeability. Brain Res 1103 (1):13-19. doi:10.1016/j.brainres.2006.05.073/S0006-8993(06)01491-0

Makihara N, Okada Y, Koga M, Shiokawa Y, Nakagawara J, Furui E, Kimura K, Yamagami H, Hasegawa Y, Kario K, Okuda S, Naganuma M, Toyoda K (2012) Effect of serum lipid levels on stroke outcome after rt-PA therapy: SAMURAI rt-PA registry. Cerebrovasc Dis 33 (3):240-247. doi:10.1159/000334664

Malchinkhuu E, Sato K, Muraki T, Ishikawa K, Kuwabara A, Okajima F (2003) Assessment of the role of sphingosine 1-phosphate and its receptors in high-density lipoprotein-induced stimulation of astroglial cell function. Biochem J 370(Pt 3):817-827. doi:10.1042/BJ20020867

Margaill I, Plotkine M, Lerouet D (2005) Antioxidant strategies in the treatment of stroke. Free Radic Biol Med 39(4):429-443. doi:10.1016/j.freeradbiomed.2005.05.003/S0891-5849(05) 00266-2

McGrath KC, Li XH, Puranik R, Liong EC, Tan JT, Dy VM, DiBartolo BA, Barter PJ, Rye KA, Heather AK (2009) Role of 3beta-hydroxysteroid-delta 24 reductase in mediating antiinflammatory effects of high-density lipoproteins in endothelial cells. Arterioscler Thromb Vasc Biol 29(6):877-882. doi:10.1161/ATVBAHA.109.184663

Miller GJ, Miller NE (1975) Plasma-high-density-lipoprotein concentration and development of ischaemic heart-disease. Lancet 1(7897):16-19 
Mineo C, Deguchi H, Griffin JH, Shaul PW (2006) Endothelial and antithrombotic actions of HDL. Circ Res 98(11):1352-1364

Moubarik C, Guillet B, Youssef B, Codaccioni JL, Piercecchi MD, Sabatier F, Lionel P, Dou L, Foucault-Bertaud A, Velly L, Dignat-George F, Pisano P (2011) Transplanted late outgrowth endothelial progenitor cells as cell therapy product for stroke. Stem Cell Rev 7(1):208-220. doi:10.1007/s12015-010-9157-y

Moudry R, Spycher MO, Doran JE (1997) Reconstituted high density lipoprotein modulates adherence of polymorphonuclear leukocytes to human endothelial cells. Shock 7(3):175-181

Mulder SD, Nielsen HM, Blankenstein MA, Eikelenboom P, Veerhuis R (2014) Apolipoproteins E and $\mathrm{J}$ interfere with amyloid-beta uptake by primary human astrocytes and microglia in vitro. Glia. doi:10.1002/glia.22619

Muller C, Salvayre R, Negre-Salvayre A, Vindis C (2011) HDLs inhibit endoplasmic reticulum stress and autophagic response induced by oxidized LDLs. Cell Death Differ 18(5):817-828. doi:10.1038/cdd2010149

Murphy AJ, Woollard KJ, Hoang A, Mukhamedova N, Stirzaker RA, McCormick SP, Remaley AT, Sviridov D, Chin-Dusting J (2008) High-density lipoprotein reduces the human monocyte inflammatory response. Arterioscler Thromb Vasc Biol 28(11):2071-2077. doi:10.1161/ ATVBAHA.108.168690

Murphy AJ, Woollard KJ, Suhartoyo A, Stirzaker RA, Shaw J, Sviridov D, Chin-Dusting JP (2011) Neutrophil activation is attenuated by high-density lipoprotein and apolipoprotein A-I in in vitro and in vivo models of inflammation. Arterioscler Thromb Vasc Biol 31 (6):1333-1341. doi:10.1161/ATVBAHA.111.226258

Navab M, Hama SY, Cooke CJ, Anantharamaiah GM, Chaddha M, Jin L, Subbanagounder G, Faull KF, Reddy ST, Miller NE, Fogelman AM (2000) Normal high density lipoprotein inhibits three steps in the formation of mildly oxidized low density lipoprotein: step 1. J Lipid Res 41 (9):1481-1494

Navab M, Anantharamaiah GM, Hama S, Hough G, Reddy ST, Frank JS, Garber DW, Handattu S, Fogelman AM (2005) D-4F and statins synergize to render HDL antiinflammatory in mice and monkeys and cause lesion regression in old apolipoprotein E-null mice. Arterioscler Thromb Vasc Biol 25(7):1426-1432

Navab M, Shechter I, Anantharamaiah GM, Reddy ST, Van Lenten BJ, Fogelman AM (2010) Structure and function of HDL mimetics. Arterioscler Thromb Vasc Biol 30(2):164-168

Negre-Salvayre A, Dousset N, Ferretti G, Bacchetti T, Curatola G, Salvayre R (2006) Antioxidant and cytoprotective properties of high-density lipoproteins in vascular cells. Free Radic Biol Med 41(7):1031-1040. doi:10.1016/j.freeradbiomed.2006.07.006/S0891-5849(06)00430-8

Nissen SE, Tsunoda T, Tuzcu EM, Schoenhagen P, Cooper CJ, Yasin M, Eaton GM, Lauer MA, Sheldon WS, Grines CL, Halpern S, Crowe T, Blankenship JC, Kerensky R (2003) Effect of recombinant ApoA-I Milano on coronary atherosclerosis in patients with acute coronary syndromes: a randomized controlled trial. JAMA 290(17):2292-2300

Nofer JR, Kehrel B, Fobker M, Levkau B, Assmann G, von Eckardstein A (2002) HDL and arteriosclerosis: beyond reverse cholesterol transport. Atherosclerosis 161(1):1-16

Nofer JR, van der Giet M, Tolle M, Wolinska I, von Wnuck LK, Baba HA, Tietge UJ, Godecke A, Ishii I, Kleuser B, Schafers M, Fobker M, Zidek W, Assmann G, Chun J, Levkau B (2004) HDL induces NO-dependent vasorelaxation via the lysophospholipid receptor S1P3. J Clin Invest 113(4):569-581

Olsson AG, Schwartz GG, Szarek M, Sasiela WJ, Ezekowitz MD, Ganz P, Oliver MF, Waters D, Zeiher A (2005) High-density lipoprotein, but not low-density lipoprotein cholesterol levels influence short-term prognosis after acute coronary syndrome: results from the MIRACL trial. Eur Heart J 26(9):890-896. doi:10.1093/eurheartj/ehi186

Ortiz-Munoz G, Houard X, Martin-Ventura JL, Ishida BY, Loyau S, Rossignol P, Moreno JA, Kane JP, Chalkley RJ, Burlingame AL, Michel JB, Meilhac O (2009) HDL antielastase activity prevents smooth muscle cell anoikis, a potential new antiatherogenic property. Faseb J 23 (9):3129-3139. doi:10.1096/fj.08-127928 
Pajkrt D, Lerch PG, van der Poll T, Levi M, Illi M, Doran JE, Arnet B, van den Ende A, ten Cate JW, van Deventer SJ (1997) Differential effects of reconstituted high-density lipoprotein on coagulation, fibrinolysis and platelet activation during human endotoxemia. Thromb Haemost 77(2):303-307

Paterno R, Ruocco A, Postiglione A, Hubsch A, Andresen I, Lang MG (2004) Reconstituted highdensity lipoprotein exhibits neuroprotection in two rat models of stroke. Cerebrovasc Dis 17 (2-3):204-211

Petoumenos V, Nickenig G, Werner N (2009) High-density lipoprotein exerts vasculoprotection via endothelial progenitor cells. J Cell Mol Med 13(11-12):4623-4635

Pfrieger FW, Ungerer N (2011) Cholesterol metabolism in neurons and astrocytes. Prog Lipid Res 50(4):357-371. doi:10.1016/j.plipres.2011.06.002

Razavian SM, Atger V, Giral P, Cambillau M, Del-Pino M, Simon AC, Moatti N, Levenson J (1994) Influence of HDL subfractions on erythrocyte aggregation in hypercholesterolemic me. PCVMETRA group. Arterioscler Thromb 14(3):361-366

Rolland WB, Lekic T, Krafft PR, Hasegawa Y, Altay O, Hartman R, Ostrowski R, Manaenko A, Tang J, Zhang JH (2013) Fingolimod reduces cerebral lymphocyte infiltration in experimental models of rodent intracerebral hemorrhage. Exp Neurol 241:45-55. doi:10.1016/j.expneurol. 2012.12.009

Rossi F, Bertone C, Montanile F, Miglietta F, Lubrano C, Gandini L, Santiemma V (2010) HDL cholesterol is a strong determinant of endothelial progenitor cells in hypercholesterolemic subjects. Microvasc Res 80(2):274-279. doi:10.1016/j.mvr.2010.05.003/S0026-2862(10) 00091-9

Rouhl RP, van Oostenbrugge RJ, Damoiseaux J, Tervaert JW, Lodder J (2008) Endothelial progenitor cell research in stroke: a potential shift in pathophysiological and therapeutical concepts. Stroke 39(7):2158-2165. doi:10.1161/STROKEAHA.107.507251

Sacco RL, Benson RT, Kargman DE, Boden-Albala B, Tuck C, Lin IF, Cheng JF, Paik MC, Shea S, Berglund L (2001) High-density lipoprotein cholesterol and ischemic stroke in the elderly: the Northern Manhattan Stroke Study. JAMA 285(21):2729-2735

Santos-Silva A, Rebelo I, Castro E, Belo L, Catarino C, Monteiro I, Almeida MD, Quintanilha A (2002) Erythrocyte damage and leukocyte activation in ischemic stroke. Clin Chim Acta 320 (1-2):29-35

Sare GM, Gray LJ, Wardlaw J, Chen C, Bath PM (2009) Is lowering blood pressure hazardous in patients with significant ipsilateral carotid stenosis and acute ischaemic stroke? Interim assessment in the 'Efficacy of Nitric Oxide in Stroke' trial. Blood Press Monit 14(1):20-25. doi:10.1097/MBP.0b013e32831e30bd

Schaefer EJ, Asztalos BF (2007) Increasing high-density lipoprotein cholesterol, inhibition of cholesteryl ester transfer protein, and heart disease risk reduction. Am J Cardiol 100(11 A): n25-n31. doi:10.1016/j.amjcard.2007.08.010

Schulz R, Kelm M, Heusch G (2004) Nitric oxide in myocardial ischemia/reperfusion injury. Cardiovasc Res 61(3):402-413

Sirtori CR, Calabresi L, Franceschini G, Baldassarre D, Amato M, Johansson J, Salvetti M, Monteduro C, Zulli R, Muiesan ML, Agabiti-Rosei E (2001) Cardiovascular status of carriers of the apolipoprotein A-I(Milano) mutant: the Limone sul Garda study. Circulation 103 (15):1949-1954

Stowe AM, Adair-Kirk TL, Gonzales ER, Perez RS, Shah AR, Park TS, Gidday JM (2009) Neutrophil elastase and neurovascular injury following focal stroke and reperfusion. Neurobiol Dis 35(1):82-90. doi:10.1016/j.nbd.2009.04.006/S0969-9961(09)00083-7

Suc I, Escargueil-Blanc I, Troly M, Salvayre R, Negre-Salvayre A (1997) HDL and ApoA prevent cell death of endothelial cells induced by oxidized LDL. Arterioscler Thromb Vasc Biol 17 (10):2158-2166

Sumi M, Sata M, Miura S, Rye KA, Toya N, Kanaoka Y, Yanaga K, Ohki T, Saku K, Nagai R (2007) Reconstituted high-density lipoprotein stimulates differentiation of endothelial progenitor cells and enhances ischemia-induced angiogenesis. Arterioscler Thromb Vasc Biol 27 (4):813-818. doi:10.1161/01.ATV.0000259299.38843.64 
Theilmeier G, Schmidt C, Herrmann J, Keul P, Schafers M, Herrgott I, Mersmann J, Larmann J, Hermann S, Stypmann J, Schober O, Hildebrand R, Schulz R, Heusch G, Haude M, von Wnuck LK, Herzog C, Schmitz M, Erbel R, Chun J, Levkau B (2006) High-density lipoproteins and their constituent, sphingosine-1-phosphate, directly protect the heart against ischemia/reperfusion injury in vivo via the S1P3 lysophospholipid receptor. Circulation 114(13):1403-1409

Thiemermann C, Patel NS, Kvale EO, Cockerill GW, Brown PA, Stewart KN, Cuzzocrea S, Britti D, Mota-Filipe H, Chatterjee PK (2003) High density lipoprotein (HDL) reduces renal ischemia/reperfusion injury. J Am Soc Nephrol 14(7):1833-1843

Tran-Dinh A, Diallo D, Delbosc S, Varela-Perez LM, Dang QB, Lapergue B, Burillo E, Michel JB, Levoye A, Martin-Ventura JL, Meilhac O (2013) HDL and endothelial protection. Br J Pharmacol 169(3):493-511. doi:10.1111/bph.12174

Tso C, Martinic G, Fan WH, Rogers C, Rye KA, Barter PJ (2006) High-density lipoproteins enhance progenitor-mediated endothelium repair in mice. Arterioscler Thromb Vasc Biol 26 (5):1144-1149. doi:10.1161/01.ATV.0000216600.37436.cf

Tsuda K, Kimura K, Nishio I, Masuyama Y (2000) Nitric oxide improves membrane fluidity of erythrocytes in essential hypertension: an electron paramagnetic resonance investigation. Biochem Biophys Res Commun 275(3):946-954. doi:10.1006/bbrc.2000.3408(S0006-291X (00)93408-9)

Tuttolomondo A, Di Raimondo D, di Sciacca R, Pinto A, Licata G (2008) Inflammatory cytokines in acute ischemic stroke. Curr Pharm Des 14(33):3574-3589

Vaisar T, Pennathur S, Green PS, Gharib SA, Hoofnagle AN, Cheung MC, Byun J, Vuletic S, Kassim S, Singh P, Chea H, Knopp RH, Brunzell J, Geary R, Chait A, Zhao XQ, Elkon K, Marcovina S, Ridker P, Oram JF, Heinecke JW (2007) Shotgun proteomics implicates protease inhibition and complement activation in the antiinflammatory properties of HDL. J Clin Invest 117(3):746-756. doi:10.1172/JCI26206

van Oostrom O, Nieuwdorp M, Westerweel PE, Hoefer IE, Basser R, Stroes ES, Verhaar MC (2007) Reconstituted HDL increases circulating endothelial progenitor cells in patients with type 2 diabetes. Arterioscler Thromb Vasc Biol 27(8):1864-1865. doi:10.1161/ATVBAHA. 107.143875

Viswambharan H, Ming XF, Zhu S, Hubsch A, Lerch P, Vergeres G, Rusconi S, Yang Z (2004) Reconstituted high-density lipoprotein inhibits thrombin-induced endothelial tissue factor expression through inhibition of RhoA and stimulation of phosphatidylinositol 3-kinase but not Akt/endothelial nitric oxide synthase. Circ Res 94(7):918-925. doi:10.1161/01.RES. 0000124302.20396.B7

Voight BF, Peloso GM, Orho-Melander M, Frikke-Schmidt R, Barbalic M, Jensen MK, Hindy G, Holm H, Ding EL, Johnson T, Schunkert H, Samani NJ, Clarke R, Hopewell JC, Thompson JF, Li M, Thorleifsson G, Newton-Cheh C, Musunuru K, Pirruccello JP, Saleheen D, Chen L, Stewart A, Schillert A, Thorsteinsdottir U, Thorgeirsson G, Anand S, Engert JC, Morgan T, Spertus J, Stoll M, Berger K, Martinelli N, Girelli D, McKeown PP, Patterson CC, Epstein SE, Devaney J, Burnett MS, Mooser V, Ripatti S, Surakka I, Nieminen MS, Sinisalo J, Lokki ML, Perola M, Havulinna A, de Faire U, Gigante B, Ingelsson E, Zeller T, Wild P, de Bakker PI, Klungel OH, Maitland-van der Zee AH, Peters BJ, de Boer A, Grobbee DE, Kamphuisen PW, Deneer VH, Elbers CC, Onland-Moret NC, Hofker MH, Wijmenga C, Verschuren WM, Boer JM, van der Schouw YT, Rasheed A, Frossard P, Demissie S, Willer C, Do R, Ordovas JM, Abecasis GR, Boehnke M, Mohlke KL, Daly MJ, Guiducci C, Burtt NP, Surti A, Gonzalez E, Purcell S, Gabriel S, Marrugat J, Peden J, Erdmann J, Diemert P, Willenborg C, Konig IR, Fischer M, Hengstenberg C, Ziegler A, Buysschaert I, Lambrechts D, Van de Werf F, Fox KA, El Mokhtari NE, Rubin D, Schrezenmeir J, Schreiber S, Schafer A, Danesh J, Blankenberg S, Roberts R, McPherson R, Watkins H, Hall AS, Overvad K, Rimm E, Boerwinkle E, TybjaergHansen A, Cupples LA, Reilly MP, Melander O, Mannucci PM, Ardissino D, Siscovick D, Elosua R, Stefansson K, O’Donnell CJ, Salomaa V, Rader DJ, Peltonen L, Schwartz SM, Altshuler D, Kathiresan S (2012) Plasma HDL cholesterol and risk of myocardial infarction: a mendelian randomisation study. Lancet 380(9841):572-580. doi:10.1016/S0140-6736(12) $60312-2$ 
von Eckardstein A, Rohrer L (2009) Transendothelial lipoprotein transport and regulation of endothelial permeability and integrity by lipoproteins. Curr Opin Lipidol 20(3):197-205. doi:10.1097/MOL.0b013e32832afd63

Wadham C, Albanese N, Roberts J, Wang L, Bagley CJ, Gamble JR, Rye KA, Barter PJ, Vadas MA, Xia P (2004) High-density lipoproteins neutralize C-reactive protein proinflammatory activity. Circulation 109(17):2116-2122. doi:10.1161/01.CIR.0000127419.45975.26

Wang H, Eckel RH (2014) What are lipoproteins doing in the brain? Trends Endocrinol Metab 25 (1):8-14. doi:10.1016/j.tem.2013.10.003

Wang M, Jiang X, Wu W, Zhang D (2013) Endothelial NO synthase gene polymorphisms and risk of ischemic stroke in Asian population: a meta-analysis. PLoS ONE 8(3):e60472. doi:10.1371/ journal.pone. 0060472

Wannamethee SG, Shaper AG, Ebrahim S (2000) HDL-cholesterol, total cholesterol, and the risk of stroke in middle-aged British men. Stroke 31(8):1882-1888

Weksler BB, Subileau EA, Perriere N, Charneau P, Holloway K, Leveque M, Tricoire-Leignel H, Nicotra A, Bourdoulous S, Turowski P, Male DK, Roux F, Greenwood J, Romero IA, Couraud PO (2005) Blood-brain barrier-specific properties of a human adult brain endothelial cell line. Faseb J 19(13):1872-1874. doi:10.1096/fj.04-3458fje

Wiggins AK, Shen PJ, Gundlach AL (2003) Delayed, but prolonged increases in astrocytic clusterin (ApoJ) mRNA expression following acute cortical spreading depression in the rat: evidence for a role of clusterin in ischemic tolerance. Brain Res Mol Brain Res 114(1):20-30

Willmot M, Gray L, Gibson C, Murphy S, Bath PM (2005) A systematic review of nitric oxide donors and L-arginine in experimental stroke; effects on infarct size and cerebral blood flow. Nitric Oxide 12(3):141-149. doi:10.1016/j.niox.2005.01.003/S1089-8603(05)00004-2

Wurfel MM, Kunitake ST, Lichenstein H, Kane JP, Wright SD (1994) Lipopolysaccharide (LPS)binding protein is carried on lipoproteins and acts as a cofactor in the neutralization of LPS. J Exp Med 180(3):1025-1035

Xu SY, Pan SY (2013) The failure of animal models of neuroprotection in acute ischemic stroke to translate to clinical efficacy. Med Sci Monit Basic Res 19:37-45

Yan J, Li L, Khatibi NH, Yang L, Wang K, Zhang W, Martin RD, Han J, Zhang J, Zhou C (2011) Blood-brain barrier disruption following subarachnoid hemorrhage may be facilitated through PUMA induction of endothelial cell apoptosis from the endoplasmic reticulum. Exp Neurol 230(2):240-247. doi:10.1016/j.expneurol.2011.04.022/S0014-4886(11)00153-1

Yang Y, Loscalzo J (2000) Regulation of tissue factor expression in human microvascular endothelial cells by nitric oxide. Circulation 101(18):2144-2148

Yatomi Y, Ruan F, Hakomori S, Igarashi Y (1995) Sphingosine-1-phosphate: a platelet-activating sphingolipid released from agonist-stimulated human platelets. Blood 86(1):193-202

Yeh PS, Yang CM, Lin SH, Wang WM, Chen PS, Chao TH, Lin HJ, Lin KC, Chang CY, Cheng TJ, Li YH (2013) Low levels of high-density lipoprotein cholesterol in patients with atherosclerotic stroke: a prospective cohort study. Atherosclerosis 228(2):472-477. doi:10.1016/j. atherosclerosis.2013.03.015

Yip HK, Tsai TH, Lin HS, Chen SF, Sun CK, Leu S, Yuen CM, Tan TY, Lan MY, Liou CW, Lu CH, Chang WN (2011) Effect of erythropoietin on level of circulating endothelial progenitor cells and outcome in patients after acute ischemic stroke. Crit Care 15(1):R40. doi:10.1186/ cc 10002

Zhang R, Zhu F, Ren J, Huang L, Liu P, Wu G (2011) Beclin1/PI3K-mediated autophagy prevents hypoxia-induced apoptosis in EAhy926 cell line. Cancer Biother Radiopharm 26(3):335-343. doi: $10.1089 /$ cbr.2010.0814 